\title{
Merkel Cell Carcinoma pT1 TNM Finding
}

v7

National Cancer Institute

\section{Source}

National Cancer Institute. Merkel Cell Carcinoma pT 1 TNM Finding v7. NCI Thesaurus.

Code C88504.

Merkel cell carcinoma with less than or equal to $2 \mathrm{~cm}$ maximum tumor dimension. (from AJCC 7th Ed.) 